\title{
Politics and Biology: The Dark Tetrad and Darkness at Noon
}

\begin{abstract}
This paper describes methodological and theoretical problematics in creating knowledge about the relations between politics and biology. These problematics are cited from philosophy and philosophy of science, critical theory, and scientific method(s). The case of politics characterized by the dark tetrad - narcissism, psychopathy, Machiavellianism, and sadism - and biology characterized by evolutionary theories are used as an example. The conclusion is that the relations between politics and biology are unknowable and attempts to apply putative knowledge of such relations have led to tragedy and atrocity throughout history.
\end{abstract}

Keywords: biology, dark tetrad, evolutionary theories, knowledge, politics

Parsing the relations between politics and biology poses an ironic, reflexive challenge. Its very parsing necessarily brings with it a priori assumptions. This is because one's analysis and conclusions about such relations necessarily presupposes at least an implicit analysis and conclusions about such relations. In other words, one cannot totally step outside of one's epistemological stance to critique it and parse the relations. One might think one is or has been born, can become or will be, or is free, but everywhere one is in epistemological chains. So on the matter of the relations between politics and biology, matters are largely settled a priori by one's very choices of concepts; their meanings; presumably relevant data matching the concepts; quantitative and qualitative analytic techniques; and conscious and unconscious hermeneutic strategies iteratively and reciprocally applied to this whole sequence.

Intellectual and cultural histories have addressed this challenge for at least several thousand years. Śruti from the Vedas are revelations - inferring from them to the nature of the relations between politics and biology often have been left to sages, but who credentials them and privileges their epistemological turns

College of Arts and Sciences / College of Security and Intelligence, Embry-Riddle Aeronautical University, Prescott, Arizona, USA. 
(Doniger O'Flaherty, 1988)? The sophist Gorgias might opine that there are no relations between politics and biology or we can know nothing about them; but if there are they cannot be known; and if they can be known they cannot be communicated (cf. Guthrie, 1971). Parsing the relations between politics and biology relates to the parser's position on the comparative import of empiricism, rationalism, and materialism as privileged positions on the road to knowledge - examples including the converse opinions of Plato and Aristotle depicted in Raphael's The School of Athens (2020/1511), Francis Bacon's Novum Organum (1994/1620), the Discourse on the Method of Rightly Conducting One's Reason and of Seeking Truth in the Sciences of René Descartes (2008/1637), and Immanuel Kant's Critique of Pure Reason (1998/1781).

The results of parsing the relations between politics and biology also may be necessarily a false consciousness with superstructure founded on one's socioeconomic context as in many Marxist theories (cf. Engels 1949/1893); necessarily compatible with consensually embraced conceptual paradigms as in Thomas Kuhn's The Structure of Scientific Revolutions (2012/1962); congruent with consensually admirable and tenable of intellectual - especially scientific - social practices as described by Bruno Latour in Science in Action: How to Follow Scientists and Engineers through Society (1987); intrinsically socially constructed as described by many critical theorists with texts and theorists having the goals of power with differential consequences for ensuring, sustaining, and multiplying life - viz., the biopolitics of Rudolf Kjellén described in Roberto Esposito's Bios: Biopolitics and Philosophy (2008) and the biopower of Michel Foucault in The Will to Knowledge (1978/1976); or the spawn of linguistic constraints via the deconstruction of Jacques Derrida's Writing and Difference (1978/1967), language games of Ludwig Wittgenstein's Philosophical Investigations (1953), social structures of Claude Lévi-Strauss from The Raw and the Cooked (1983/1964), and the transformational grammar of Noam Chomsky's Syntactic Structures (1957). Again ironically and reflexively in the context of politics and biology, parsing itself may be subject to evolutionary pressures as in the traditions of evolutionary epistemological mechanisms (EEM) and evolutionary epistemology of theories (EET) described by Michael Bradie in "Epistemology from an Evolutionary Point of View" in Elliott Sober's Conceptual Issues in Evolutionary Biology (1994), and the naturalized epistemology of Willard Van Orman Quine in his Ontological Relativity and Other Essays (1969).

Be that as it may, there's a long tradition of parsing the relations between politics (as in the psychology of living within the polis) and biology. Presumed correlational/causal biological factors include bodily fluids such as humors (c. Alcmaeon of Croton, Hippocrates in the $5^{\text {th }}-4^{\text {th }}$ centuries BCE); secretions of endocrine glands and neuronal synapses, and more recently discovered interactions with the gut microbioeme (Weir, 2018); systems of brain and nervous system function varying in the import of specific neural areas, processes, and 
structures (Kalat, 2018); invasive effects on brain tissue from lobotomies, lobectomies, and direct cranial electromagnetic stimulation (Sachdev \& Chen, 2009); external physical appearance whether from skull size and shape (e.g., the phrenology of Francis Gall (Pereira, 2017)), facial structure described in the history of physiognomy (cf. Boys-Stones et al., 2007), the body mass index and musculature as in William Sheldon's constitutional psychology (Klineberg, 1941), facial expressions linked to emotions, e.g., Paul Ekman's Facial Action Coding Systems (Ekman, 1994); and the evolutionary theories stemming from Charles Darwin and Alfred Russel Wallace varying on where on a biopsychosocial continuum including political aspects - are adaptive phenomena defined as increasing the probability of one's physical survival and passing on one's own genes to one's own descendants and having them expressed, presumably on a continuum of consanguinity from first degree relatives through conspecifics (Buss, 2020).

There are case histories and anecdotes on the relations between politics and biology based on combinations of all the above. These include presumed epileptic seizures and depression as medical disease linked to the disastrous politico-military decisionmaking of King Saul in the Hebrew Bible (or Tanakh); the inferred physical characteristics presumably spawning political success and failure in Plutarch's Lives of the Noble Greeks and Romans (c. $100 \mathrm{CE}$ ); and more recent examples such as the domestic, foreign, and national security policy management around the cardiovascular disease and strokes of United State President Woodrow Wilson as described by Alexander and Juliette George in Woodrow Wilson and Colonel House: A Personality Study (1964) and those described from Lenin to Idi Amin in Jerrold Post's and Robert Robins's When Illness Strikes the Leader: The Dilemma of the Captive King (1993).

With all the above as preamble and context, the rest of this paper will focus on the relations between politics characterized by the psychological dark tetrad (viz., narcissism, psychopathy, Machiavellianism, and sadism) affecting cooperation and competition in the polis and biology characterized by evolutionary theories. Of special note will be not only attempts to discern the nature of such relations but their degree of mutability.

The first problem is coming to an appropriate definition of the dark tetrad - a problem which might well deter attempts to offer one. Although narcissism and the rest often refer to specific behaviors often maligned as unethical, immoral, and/or illegal, the essence of each aspect of the tetrad constitute intrapsychic phenomena. These phenomena, in turn, constitute nomological networks presumed leading to behavioral intentions, behaviors, and then these behaviors' consequences. Phenomena and nomological networks are inferred from the initiating political actor's self-report, collateral sources' reports about the initiating and target political actors, target political actors' behaviors and self-reports, and/ or reports from professional and lay theorists and/or analysts a posteriori. All are employing explicit and implicit aspects of their belief systems about the nature of 
the social world. For all, an identical behavior may be interpreted quite differently based on their own belief systems, their interpretations of the social context within which the behavior appears to be situated, and their differential motivational states affecting social perception. Inferences about intrapsychic phenomena often become reified, that is, one ascribes some ontological reality to what may not be real. The titles of two articles written by the late Gestalt psychologist Mary Henle "On the Distinction between the Phenomenal and Physical Object" (1986) and "Episodes in the History of Interaction: On Knowing What One is Talking About" (1986) get at the heart of the matter. The four aspects of the dark triad are often employed as negative attributions towards initiating political actors much more often than there's consensus on what they mean beyond this exchange value. And as with some people stigmatized by negative attributions bearing on race, ethnicity, or sexual orientation (e.g., NWA, the rap group of the late 1980s, and the construct 'queer'), the four aspects of the dark triad can even be reversed into positive attributions.

Nevertheless, whatever the dark tetrad might mean, there's a second problem - the post hoc theorizing by evolutionary theories supporting the attribution of adaptiveness to narcissism, psychopathy, Machiavellianism, and sadism. Allegedly, sometime in the past the tetrad - all or in come combination - conferred advantage as to the probability of one's physical survival linked to passing on one's own genes to one's descendants and having them expressed, presumably on a continuum from first degree relatives through conspecifics. This post hoc theorizing of adaptiveness as with much of psychodynamic theorizing on psychological conflict yields face valid hypotheses that seem impervious to refutation, especially with the tools of further post hoc theorizing and critiquing constrained only by face validity. How far back in time is too long or not long enough to demonstrate such adaptiveness? When does such adaptiveness no longer apply? Even if still adaptive, when might the tetrad be overidden by more proximal social and cultural factors - including beliefs that the tetrad is or is not adaptive? Such matters have bearing on whether leaders of a polis, individuals intending to become or who support or oppose leaders of a polis, and even parents raising their children would desire to let Mother Nature take her course - to work around the tetrad, exploit it, employ it - or somehow attempt to modify or divert it.

The third problem is that even if somehow adaptive, the variance of aspects of the tetrad - the difference in the frequencies with which they appear within, between, and among individuals through life - are necessarily impacted and situated within many biological and environmental sources as follows. First, additive genetic variation. Second, variance from interactions between genes. Third, variance from an individual's or population's shared environmental factors. Fourth, variance from correlations within, between, and among genetic and environmental factors. Fifth, variance from interactions within, between, 
and among genetic and environmental interactions. And sixth, variance from anything else not already accounted for. All this relates to the common misconception that heritability has anything to do with genotypes causing phenotypes as opposed to how much genetic variability has to do with phenotypic variability - viz., the variability of the dark tetrrad. Such matters bear on whether Mother Nature takes her course, should take this course, or should be challenged through attempts at modification or diversion.

The fourth problem is that the dark tetrad may have first appeared and remained at varying levels of frequency, intensity, and quality as part of politics without being adaptive itself, but as a non-adaptive side consequence of other psycho-political adaptations. Or there may have been be fluctuations through time wherein the dark tetrad is adaptive then a non-adaptive side consequence. Or yet again the dark triad may just be noise amidst the signals and noise manifested by other psych-political phenotypes.

But pursuit of relations between politics characterized by the dark tetrad and biology characterized by evolutionary theories may most of all be impeded by the human sciences' continued emulation of the Newtonian physics of the $17^{\text {th }}$ to early $18^{\text {th }}$ centuries as opposed to the quantum physics of the $20^{\text {th }}$ and $21^{\text {st }}$. Why as by rote remain enmeshed in paradigms with the much simpler mathematics especially statistics; static conceptions of the nature of space and time; insistence on the utility and validity of Aristotelian logics such as the laws of the excluded middle and of identity; discounting the degree to which even the so-called unobtrusive and non-reactive measurement techniques characterizing the evolutionary epistemology of social scientists like Donald Campbell (Webb et al., 1966) are neither unobtrusive nor non-reactive; and the non-acceptance of the possibility of political phenomena including the dark triad being simultaneously constituted in diverse ways as in the quantum superposition and entanglement conceived via thought experiment by the physicist Erwin Schrödinger (Moore, 1992)? Why assume that political phenomena are so much simpler than physical ones given huge divergences of understanding, controllability, and prediction on matters of war, peace, and political leadership, strategy, and tactics among government, business, and academic experts - the last both socially recognized and self-appointed?

So, if knowing denotes something we believe, can justify and is true, what can we know about the relations between politics characterized by the dark tetrad and biology characterized by evolutionary theories? Depending on our stance on the desirability of politics characterized by the dark tetrad, we might watch the clock of evolutionary time for the dark tetrad's adaptiveness to increase or decrease. Or we might intentionally make modifications in the political environment to speed up or slow down the clock. Assuming that B.F. Skinner is correct in his Beyond Freedom and Dignity (1971) that political behavior - both verbal and otherwise - is controlled by the reinforcement, training and punishment 
of operant conditioning and associated discriminative stimuli, modifying the political environment would be the key. However, the improbability of coming up with and implementing the right schedules of stimuli and consequences, the right schedules of reinforcement, should stop us in our tracks, even if the likelihood of a road to serfdom through such social control wouldn't (cf. Hayek, 2007/1941).

Based on the various analyses in this paper, it may be that the relations between politics characterized by the dark tetrad and biology characterized by evolutionary theories are unknowable. For those of us who desire a world of peace, cooperation, large degrees of freedom tempered with the constraint of minimally hurting others, cultivating our garden like Voltaire's Candide (1959/1759), this might well be unfortunate. Narcissism, psychopathy, Machiavellianism, and sadism - whether at clinically pathological levels or not, whether directly assessed with psychodiagnostic instruments and interviews or inferred via contemporary or historical data - are prevalent in the human history of atrocities. This is the case even as they also can be identified and perhaps sublimated in professional successes in government, business, and academia.

Yet, confronted with terrorism, torture, war crimes, genocide, crimes against humanity along with justifications by perpetrators and their supporters, we might still seize upon the belief that we do or can know the relations between the dark tetrad and evolutionary theories or other theories and models of biology implicitly or otherwise. And through this knowledge change the world for the better. According to terror management theory, such a belief wards off feelings of mortality (Solomon et al., 2015). Analogous to comparative philosophies on man making God and God making man (cf. Feuerbach, 1989/1841), such a belief renders the world more orderly and understandable. Such a belief also is consonant with a common belief that on a continuum of science from physics to political science, the latter is subsumed by the former in ultimate explanatory power.

The need to believe can be so strong that we can willingly engage in false confessions for heinous crimes, sometimes actually believing we have committed what we have not or that we deserve to be treated as if we committed them. This can occur during interrogation about the commission of felonies like premeditated murder, seemingly correlated with a host of biopsychosocial variables (Scherr et al., 2020). It can also occur during political show trials whether anteceded by interrogation and even torture or not.

An exemplary novelistic depiction of this latter phenomenon is Arthur Koestler's Darkness at Noon, originally entitled The Vicious Circle (1941/1940). The more recent and well-known title is from Job 5:14: "They meet with darkness in the daytime, and grope in the noonday as in the night". The novel creates an all pervading political darkness wherein the human will is broken and human corruptness is wielded in the service of power. The reader of Darkness can 
be excused for looking for any pathway towards the light, even that of some biological fix. But the history of such biological fixes - eugenics, genocide, medicalizing political opposition through psychiatry - only have yielded darkness.

I write this at a time of global darkness from a new coronavirus, dismal socioeconomic prospects for many global citizens, and political, ethnocentric and racialized conflict. It may well be that politics characterized by the dark tetrad will remain recalcitrant to understanding, prediction, and control via biology and otherwise. And darkness at noon with its vicious circle, a heart of darkness, may remain our fate.

\section{References}

Bacon, F. (1994/1620). Novum Organum, trans., eds. P. Urbach, J. Gibson. Peru, IL: Carus Publishing Co.

Boys-Stones, G., Elsner, J., Ghersetti, A., Hoyland, R., Repath, I., Swain, S. (2007). Seeing the Face, Seeing the Soul: Polemon's Physiognomy from Classical Antiquity to Medieval Islam, ed. S. Swain. Oxford, UK: Oxford University Press.

Bradie, M. (1994). "Epistemology from an Evolutionary Point of View". In: E. Sober (ed.). Conceptual Issues in Evolutionary Biology. Cambridge, MA: MIT Press, pp. 453-476.

Buss, D.M. (2020). "Evolutionary Psychology is a Scientific Revolution". Evolutionary Behavioral Sciences, https://psycnet.apa.org/fulltext/2020-31396-001.pdf (accessed: 8.06.2020).

Chomsky, N. (1957). Syntactic Structures. The Hague-Paris: Mouton.

Derrida, J. (1978/1967). Writing and Difference, trans. A. Bass. Chicago, IL: The University of Chicago Press.

Descartes, R. (2008/1637). Discourse on the Method of Rightly Conducting One's Reason and of Seeking Truth in the Sciences, https://www.gutenberg.org/files/59/59-h/59-h. htm (accessed: 8.06.2020).

Doniger O'Flaherty, W. (1988). Textual Sources for the Study of Hinduism. Manchester: Manchester University Press.

Ekman, P. (1994). "Strong Evidence for Universals in Facial Expressions: A Reply to Russell's Mistaken Critique”. Psychological Bulletin, 115(2), pp. 268-287.

Engels, F. (1949/1893). "Letter to F. Mehring". In: Karl Marx and Friedrich Engels: Selected Works in Two Volumes, Vol. II. Moscow, RU: Foreign Languages Publishing House.

Esposito, R. (2008). Bios: Biopolitics and Philosophy, trans. T. Campbell. Minneapolis, MN: University of Minnesota Press.

Feuerbach, L. (1989/1841). The Essence of Christianity, trans. G. Elliot. Amherst, NY: Prometheus Books.

Foucault, M. (1978/1976). The Will to Knowledge: The History of Sexuality, Vol. 1, trans. R. Hurley. New York: Pantheon Books.

George, A.L., George, J.L. (1964). Woodrow Wilson and Colonel House: A Personality Study. Mineola, NY: Dover Publications.

Guthrie, W.K.C. (1971). The Sophists. New York: Cambridge University Press. 
Hayek, F.A. (2007/1941). The Road to Serfdom, trans. B. Caldwell. Chicago, IL: The University of Chicago Press.

Henle, M. (1986). "Episodes in the History of Interaction: On Knowing What One is Talking About". In: M. Henle (ed.). 1879 and All That. New York: Columbia University Press, pp. 10-21.

Henle, M. (1986). "On the Distinction between the Phenomenal and Physical Object”. In: M. Henle (ed.). 1879 and All That. New York: Columbia University Press, pp. 3-9.

Kalat, J.W. (2018). Biological Psychology. Boston, MA: Cengage Learning.

Kant, I. (1998/1781). Critique of Pure Reason, trans., eds. P. Guyer, A.W. Wood. New York: Cambridge University Press.

Klineberg, O. (1941). "Review of The Varieties of Human Physique: An Introduction to Constitutional Psychology”. Psychological Bulletin, 38(8), pp. 750-751.

Koestler, A. (1941/1940). Darkness at Noon. New York: Scribner.

Kuhn, T.S. (2012/1962). The Structure of Scientific Revolutions. ( $4^{\text {th }}$ Ed.). Chicago, IL: The University of Chicago Press.

Latour, B. (1987). Science in Action: How to Follow Scientists and Engineers through Society. Cambridge, MA: Harvard University Press.

Lévi-Strauss, C. (1983/1964). The Raw and the Cooked. Mythologiques, Vol. 1, trans. J.D. Weightman. Chicago, IL: The University of Chicago Press.

Moore, W. (1992). Schrödinger: Life and Thought. Cambridge, UK: Cambridge University Press.

Pereira, D.R. (2017). "Revisiting the Contributions of The New Phrenology to the Brainmind Debate". Journal of Theoretical and Philosophical Psychology, 37(3), pp. 152163.

Plutarch. (c. 100). Lives of the Noble Grecians and Romans, http://www.gutenberg.org/ebooks/674 (accessed: 8.06.2020).

Post, J., Robins, R. (1993). When Illness Strikes the Leader: The Dilemma of the Captive King. New Haven, CN: Yale University Press.

Quine, W.V.O. (1969). Ontological Relativity and Other Essays. New York: Columbia University Press.

Raphael. (2020/1511). The School of Athens, http://www.clio.unina.it/ alfredo/index. php?mod=05_Interessi\%2FLa_Scuola_di_Atene (accessed: 8.06.2020).

Sachdev, P.S., Chen, X. (2009). "Neurosurgical Treatment of Mood Disorders: Traditional Psychosurgery and the Advent of Deep Brain Stimulation". Current Opinion in Psychiatry, 22(1), pp. 25-31.

Scherr, K.C., Redlich, A.D., Kassin, S.M. (2020). "Cumulative Disadvantage: A Psychological Framework for Understanding How Innocence Can Lead to Confession, Wrongful, Conviction, and Beyond". Perspectives on Psychological Science, 15(2), pp. 353-383.

Skinner, B.F. (1971). Beyond Freedom and Dignity. New York: Knopf.

Solomon, S., Greenberg, J., Pyszczynski, T. (2015). The Worm at the Core: On the Role of Death in Life. New York: Random House.

Voltaire (François-Marie Arouet). (1959/1759). Candide, trans. L. Bair. New York: Bantam Dell. 
Webb, E.J., Campbell, D.T., Schwartz, R.D., Sechrest, L. (1966). Unobtrusive Measures: Nonreactive Research in the Social Sciences. Oxford, England: Rand McNally.

Weir, K. (2018). “The Future of Psychobiotics”. Monitor on Psychology, https://www.apa. org/monitor/2018/12/cover-psychobiotics (accessed: 8.06.2020).

Wittgenstein, L. (1953). Philosophical Investigations, eds. G.E.M. Anscombe, R. Rhees, trans. G.E.M. Anscombe. Oxford, UK: Blackwell. 
